\title{
Journalistik som en hermeneutisk og dekonstruktiv intervention i den distribuerede offentlighed
}

\author{
AF EJVIND HANSEN
}

\begin{abstract}
Internettet har sat nye betingelser for den demokratiske offentlighed. Den journalistiske praksis er født ind i nogle opgaver, der opstod sammen med massemediernes fremkomst. I takt med at de traditionelle massemedier (tryk, radio, tv) afløses af internetmedier, rejser spørgsmålet sig, om vi stadig har brug for journalistikken. Jeg vil argumentere for, at der i forhold til idealer om en deliberativ offentlighed ligger tre overordnede journalistiske opgaver: (a) traditionelle opgaver som formidling, efterforskning og kritik; (b) moderation af dialoger (sikre en passende diversitet mellem de talende); (c) moderation af tavshed (give stemme til de tavse interesser i samfundet).
\end{abstract}

\section{Historisk baggrund}

I ethvert demokratisk samfund er offentlighedens struktur helt afgørende. Strukturen på offentligheden afgøres af mange ting, men en af de helt uomgængelige faktorer er den teknologi, der bærer offentligheden (Habermas 1962/1990).

Det græske demokrati havde sin ekklesia - folkeforsamlingen. Her mødte man personligt frem og lyttede til synspunkter og argumenter - primært fra de velstillede mænd over 20, der havde mulighed for at tage sig tid til den slags, og som havde retoriske evner, der gjorde, at folk gad lytte. Offentlighedens teknologi var 
primært den menneskelige stemme, mimik og gestik. Denne teknologi rummer nogle ulemper i forhold til bestandighed (udtrykket er kun sanseligt tilgængeligt i nuet og afhænger herefter af den menneskelige hukommelse) og geografisk rækkevidde (man er nødt til at være til stede for at få kendskab til, hvad der foregår). Til gengæld rummer den nogle fordele, i og med at der er en direkte kontakt mellem afsender og modtager. Man får som afsender en direkte fornemmelse af, hvordan ytringerne modtages. Og man har som modtager adgang til alle de prosodiske og ekstralingvistiske elementer (såsom tonefald, mimik, gestik), som giver en mere detaljeret forståelse af det sagte.

Det moderne vestlige demokratis fremkomst falder på mange måder sammen med teknologiske nybrud for offentligheden. Mest afgørende er givetvis massemediernes fremkomst. Trykpressen udvikles fra midten af 1400-tallet og effektiviseres for alvor i 1800-tallet, hvor damptrykpressen udvikles og effektiviseres. I 1900-tallet suppleres de papirbårne massemedier (primært avis, magasin, bog) med æterbårne massemedier som radio og tv. Dermed blev det muligt at have en offentlighed med større geografisk og modtagermæssig rækkevidde. ${ }^{1}$ Det samfundsmæssige fællesskab kunne tilsvarende udvides til ikke blot at omhandle dem, som man møder i dagligdagen. Massemedierne skabte et kommunikativt udgangspunkt for et fællesskab, der rækker ud over de faktiske, konkrete fysiske møder mellem mennesker (Anderson 1991, kap. 3). I og med at fællesskabet blev større, blev det imidlertid også påtrængende at professionalisere kommunikationen. Det kræver nogle særlige kompetencer at kommunikere med nogen, som man ikke umiddelbart kan sanse. Dels fordi man jo ikke kan vide, hvordan de reagerer. Dels fordi man ikke kender deres forudsætninger. Dertil kommer, at når publikum bliver så stort, bliver det også mere sammensat. Derfor bliver de potentielt relevante emner flere og forudsætningerne for at forstå budskaberne mere forskellige.

Den journalistiske profession er i en vis forstand defineret ved at skulle løse denne udfordring. Dermed ikke være sagt, at udfordringen var løst med journalistens fremkomst. Jeg har i en anden sammenhæng (Hansen 2013) argumenteret for, at den journalistiske praksis i en væsentlig forstand var sat på opgaver, der skulle, men i en vis forstand ikke kunne løses. Den journa- 
listiske opgave var at formidle information og kritisk ${ }^{2}$ formidle synspunkter og budskaber mellem nyhedsskabere (magthavere, eksperter og andre centrale aktører i samfundet) og nyhedsmodtagere (den almindelige borger). Men når medierne når så bredt ud, så bliver den potentielt relevante information enorm. Men borgernes evne til at indtage information er stadig lige begrænset. Derfor skal journalistikken på den ene side fremskaffe relevant information, på den anden side skal denne information begrænses mest muligt til det absolut relevante - informationer skal udvælges og tilskæres for at skabe en kommunikation, der er gennemsigtig. Men da borgerne lever forskellige liv, vil deres normer for relevans også kunne variere markant, og normerne for den "rette" selektion kan ikke forventes at være de samme for alle modtagere. Journalistikken i massemedierne er således stillet over for en opgave om at fremskaffe mest mulig information, men samtidig tilskære informationerne efter kriterier, som ikke er fælles for alle modtagerne. I første omgang gør man set fra et samfundsperspektiv en dyd ud af nødvendigheden, idet man netop ikke foregiver at repræsentere alle borgere, men primært bestemte interesser. I anden halvdel af det 20. århundrede forsøger man som svar på disse udfordringer at orientere sig efter høje standarder for fairness, objektivitet osv. (se f.eks. Bjerg 2009, særligt kap. 3-6), men disse idealer undermineres efterhånden af filosofiske pointer om, at idealerne - eller i det mindste deres konkrete virkeliggørelse - kan diskuteres. ${ }^{3}$ Pragmatiske (f.eks. i Dewey 1957, kap. V; Rorty 1979; 1989), hermeneutiske (Husserl 1935-36; Heidegger 1927), kritisk teoretiske (Adorno 1966; Honneth 1992), poststrukturalistiske (Derrida 1967; Foucault 1969) og postmoderne (Lyotard 1979) analyser har (for bare at nævne nogle få) vist, at idealerne er indlejrede i historiske og sproglige udviklinger og strukturer, der måske nok retfærdiggør deres eksistens, men ikke kan legitimere en universel ubetvivlelighed. Begreber om fairness og objektivitet har altid en bias, som potentielt kan diskuteres.

Siden 1990'erne er internettet blevet en uomgængelig del af vores offentlighed. I forhold til den beskrivelse af en journalistisk kernekompetence, som jeg har givet her, kan man sige, at internettet i nogen udstrækning løser det grundproblem, som journalistikken var sat til at løse: Internettet har både struktur 
og teknologisk rummelighed til principielt set at kunne rumme alle de informationer, der kan præsenteres visuelt og auditivt. ${ }^{4}$ Samtidig modvirkes den truende uoverskuelighed af forskellige typer af indekserings-bots (robotter, der trawler hele internettet igennem og indekserer det fundne efter forskellige kriterier, således at man efterfølgende kan søge i informationerne) og sociale netværk, hvor man kan følge hinanden og dele oplevelser med brugere, som man har fælles interesser med. Robotterne og de sociale netværk giver brugerne mulighed for at lave en personlig fokusering af informationsindtaget - suppleret med, at de store aktører på internettet har fundet ud af, at det er kommercielt attraktivt at aflure brugernes interesser og så servere indhold, der modsvarer disse (Pariser 2011; Andrejevic 2007).

Så internettet rummer med andre ord mulighed for at løse den journalistiske udfordring - vel at mærke uden at det opleves som et problem: Man kan både lægge alle informationer frem (i det mindste for så vidt man ønsker det), og brugerne har mulighed for at sortere dem i forhold til personlige kriterier for relevans. Dertil kommer, at den formidlende opgave mellem nyhedsskabere og nyhedsbrugere måske er mindre påtrængende i takt med, at nyhedsskaberne selv bevæger sig ud i den kommunikative relation (f.eks. opretter Facebook- og Twitter-profiler, hvorfra man kommunikerer direkte med nyhedsbrugerne). Dette vil vi dog vende tilbage til nedenfor.

Denne situation har naturligvis ført til en diskussion af, hvorvidt vi i offentligheden stadig har brug for den journalistiske profession. Hvis man tager ordet "brug" i den bredeste forstand, så er den betænkelighed åbenlyst forfejlet. Når vi kigger rundt $\mathrm{i}$ verden, så er der helt åbenlyst masser af brug for journalister. De løser dagligt store mængder af påtrængende opgaver, i og med at medier og organisationer har store produktionsbehov, som journalister har kompetence til at løse.

Betænkeligheden skal derfor forstås lidt mere snævert: Ligger der stadig journalistiske opgaver, som er vigtige i en form for moralsk eller demokratisk forstand, og som ikke bliver løst af sig selv gennem teknologien? Findes der stadig nogle opgaver, der er påtrængende, ikke blot $\mathrm{i}$ kommerciel forstand (hvilket naturligvis kan være vigtigt nok i sig selv), men også i en samfundsmæssig forstand? Er det med andre ord vigtigt for samfundet som helhed, 
at vi bliver ved med at uddanne journalister til at lave produkter, der ikke blot finder interesserede modtagere, men som også kan løfte disse modtagere til at være mere kompetente borgere i et demokratisk samfund? Det følgende bud på et svar vil primært læne sig op af et deliberativt ideal for repræsentativt demokrati (Habermas 1992, kap. 8). ${ }^{5}$

Hvis journalistikken er født ud af et problem med at formidle en uendeligt kompleks verden på en måde, der er tilgængelig for borgeren ifølge dennes normer for relevans, så er det naturligvis ikke en given ting, at journalistikken bliver ved med at være relevant, hvis opgaven løses andetsteds. På den anden side er det heller ikke en given ting, at journalistikken nødvendigvis bliver irrelevant af den grund. For det første kan der restere andre vigtige opgaver fra den oprindelige udfordring. For det andet kan den journalistiske profession ændre sig og tilpasses den nye situation. For at det skal blive relevant, kræver det imidlertid en overvejelse af, hvilke nye behov der måtte være opstået i internetbårne offentligheder - behov igen forstået som deliberativt demokratiske behov.

\section{Behovet for traditionel journalistisk intervention}

Journalistik i den traditionelle forstand (dvs. journalisten som mediator/formidler af information) har stadig en umiddelbar relevans på en række punkter. Jeg vil komme ind på tre opgaver: (a) en formidlings-, (b) en efterforsknings- og (c) en kritisk opgave. For alle tre gælder, at journalisten ikke per automatik er den mest kompetente, men alt andet lige vil han/hun (f.eks. gennem sin uddannelse) være bedre klædt på end flertallet.

(a) Formidlingsopgaven: I den traditionelle opgave for journalistikken er en særlig formidlingsopgave påtrængende, men det handler ikke blot om formidling som det, journalisten siger/ skriver/viser. Den side af formidlingen er naturligvis også vigtig: Den journalistiske opgave består ikke blot i at videresende vigtig information. Informationen skal også formidles, således at den bliver tilgængelig for modtagerne. Men i arbejdet med at danne grobund for denne formidlingsopgave skal den journalistiske 
agent også selv bevæge sig ind på et felt, som han/hun ikke er hjemmevant i.

Traditionelt har denne opgave været løst ved, at journalisten som ikke-ekspert bevæger sig ind på ekspertens område og udfordrer den viden, som eksperten repræsenterer, med ikkeekspertens spørgsmål. Herved tvinges eksperten til at formulere sine indsigter ind i de rammer, som ikke-ekspertens spørgsmål sætter. Gennem dette arbejde kan viden vandre på tværs af kompetenceniveauer: Når dette arbejde gøres godt, bliver en forenklet udgave af ekspertens viden tilgængelig for ikke-eksperten.

Internettet rummer også informationer og fællesskaber, der taler til vidt forskellige kompetenceniveauer. Her kan man finde informationer fra offentligt administrative institutioner, entusiastiske nørder, glade amatører, eksperter, interesseorganisationer osv. Og for nogle af disse gælder givetvis, at der finder en vis vandring mellem kompetenceniveauer sted. Men kun meget få steder (f.eks. i forbindelse med uddannelsesinstitutioner) vil man systematisk kunne regne med, at kompetencevandringen anses for at være en decideret opgave. Derfor kan det være relevant at bevare en profession, der anser dette for at være et centralt omdrejningspunkt.

(b) Efterforskningsopgaven: Internettet løser tilgængelighedsopgaven og opgaven med at sortere i den tilgængelige information. Så når informationerne er åbent tilgængelige, så er internettet et stærkt medie, fordi vi kan kombinere og søge i den på kryds og tværs.

Ikke alle relevante informationer er imidlertid per automatik åbent tilgængelige. For det første er nogle informationer grundlæggende svært tilgængelige (bl.a. fordi ikke alle relevante informationer kan sanses direkte). For det andet kan private interesser nogle gange tale for, at informationer af offentlig interesse ikke skal være offentligt tilgængelige - nogle gange af legitime grunde, andre gange af mere suspekte grunde. I samfundet har vi derfor brug for, at nogen har til opgave at grave informationer frem. Derfor har vi forskningsinstitutioner, et efterforskende politi og undersøgende journalister.

Internettet kan meget vel være et vigtigt redskab i dette arbejde, men det kan naturligvis ikke erstatte det. Derfor har vi 
stadig brug for traditionel, informationsfokuseret undersøgende (gravende) journalistik til dette arbejde.

(c) Den kritiske opgave: Internettet er som nævnt stærkt til at give brugerne informationer, der modsvarer deres personlige relevanskriterier. Det er imidlertid ikke en given ting, at brugerne altid interesserer sig for det, som de burde interessere sig for. Og dette udnyttes i megen strategisk kommunikation, hvor professionelle kommunikatører strategisk kan føre den offentlige interesse væk fra prekære problemstillinger, hvorved borgerne risikerer at få en skæv opfattelse af, hvad der er påtrængende problemstillinger, hvad der er mulige løsningsmodeller, og hvem der bør have ansvaret for at løse problemerne. Her ligger stadig en påtrængende opgave i på den ene side at give brugerne/borgerne et kvalificeret modspil, således at de ikke altid kun får det, som de af sig selv opsøger. Og på den anden side at give de professionelle kommunikatører et kritisk modspil, således at det bliver sværere at manipulere med den offentlige dagsorden.

Kigger man ovenstående tre bud igennem, kunne man godt konkludere, at journalistikken er lige så vigtig som altid. Problemet er imidlertid, at der efterhånden er opstået så mange alternative veje til information, som går uden om de journalistiske medier. Alternativer, der ikke af nogen kompetent analytiker ville blive karakteriserede som journalistisk funderede, og som heller ikke forpligter sig til publicistiske opgaver (f.eks. Facebook, Twitter, Reddit, Wikipedia, YouTube, IMDb). Disse alternativer er altså egentlig ikke journalistiske - men de bruges bare alligevel ofte som erstatninger for de journalistiske medier (Debrouwere 2012).

Det er isoleret set ikke et problem, at borgerne får informationer fra andre kilder. Problemet opstår først, når vi indser, at disse alternativer ikke på samme måde har indløsningen af de tre ovennævnte bud som en decideret opgave. De sociale medier kan godt (a) rumme formidlende stof, men lige så ofte er det primært ligestillede, der kommunikerer med ligestillede. De kan godt (b) bruges som et sted til at offentliggøre skjulte informationer, men sjældent har aktørerne egentlige kompetencer og ressourcer til at gøre det. Og særligt på (c) den kritiske opgave ligger 
en udfordring, idet sociale medier netop er tænkt som værktøjer til at udveksle den information og dialog, som man interesserer sig for i forvejen (Pariser 2011).

I takt med at borgerne (eller brugerne) får tilfredsstillet deres umiddelbare behov for information andre steder end i de journalistiske medier, kan det derfor være en god ide at overveje, om der er andre opgaver, som kunne trænge til en journalistisk håndsrækning. Spørgsmålet i resten af denne artikel vil derfor være, om det er muligt at opsøge opgaver i de nye offentligheder, hvor der er et demokratisk kald på journalistisk intervention.

\section{Behovet for moderation af dialog}

At opsummere de nye internetbaserede medier i få ord er grundlæggende set altid reduktivt. Helt uden en vis opsummering kommer vi imidlertid heller ikke langt med at skitsere en mulig fremtidig rolle for journalistikken. Jeg har derfor i andre sammenhænge (f.eks. i Hansen 2011; Hansen 2013) foreslået, at vi griber fat i internettets dialogiske struktur, når vi skal forstå, hvilke kommunikative udfordringer vi kan forvente, at den demokratiske offentlighed kommer til at stå i, i takt med at den bliver mere og mere internetbaseret.

Påstanden er ikke, at internetmedier altid er dialogiske og interaktive. Rigtig mange internetmedier har meget begrænset rum for dialogisk udveksling. Dertil kommer, at en vis grad af dialog også har fundet sted i andre medier. Alligevel giver det god mening at holde fast ved det dialogiske element som noget særligt for internettet, fordi internettet allerede på det teknologiske plan rummer en grundlæggende tovejsstruktur, der adskiller sig fra de papirbårne massemedier og radio/tv. Internettets protokoller kræver simpelthen en mulighed for tovejskommunikation for overhovedet at give rum for informationsudveksling. En teknologisk tovejsstruktur giver ikke i sig selv et dialogisk medie (Hansen 2009a), men historisk er aktivitet på en hjemmeside blevet en vigtig faktor i vurderingen af sidens kommercielle værdi (bl.a. fordi det fortæller mulige annoncører, hvor mange brugere der findes på siden, og hvor involverede de er), og her 
spiller dialog en vigtig rolle. Hvis man som internetmedie kan skabe en frugtbar dialogisk kultur, er man derfor stillet stærkt.

Dialog er imidlertid mange ting. I sin grund er dialogen ganske vist blot en gensidig udveksling af udsagn mellem mindst to parter, hvor udsagnene forholder sig til hinanden. Historisk har dialog imidlertid ofte været fremhævet som noget særligt og godt i den menneskelige sameksistens. Gode dialoger kan føre til nær social kontakt mellem mennesker, man udfordres, og man lærer noget. Denne slags dialoger er både følelsesmæssigt behagelige og intellektuelt udfordrende.

Men der findes også andre typer af dialog. Dialoger kan f.eks. være frustrerende; enten fordi man ikke føler, at man egentlig kommer i kontakt med hinanden, eller fordi man allerede kender hinanden alt for godt og derfor ikke rigtig har noget at sige til hinanden. Disse former for dialog er hverken følelsesmæssigt eller intellektuelt tilfredsstillende. Andre gange har vi dialoger, hvor vi ikke egentlig søger at udfordre hinanden, men dialogen skal bare skabe et rart samvær, hvor vi bekræfter hinanden. Det kan f.eks. være den snak, man har med sin ægtefælle, når dagen er ovre, og børnene er lagt til ro. Men det kan også være, hvis man lige har været til et agilitystævne med sin golden retriever, og man efterfølgende tweeter eller sms'er et "tak for sidst”. Endelig findes der dialoger, som man indgår i, fordi man skal. Det kan være, når man skal snakke om ubehagelige problemer eller udfordringer, som bare er nødvendige at få fra hånden. Her kan dialogerne være følelsesmæssigt ubehagelige, men intellektuelt udfordrende.

Set ud fra et kommercielt synspunkt er det afgørende, at brugerne har lyst til at blive ved med at vende tilbage og være aktive. Ud fra et deliberativt demokratisk synspunkt vil det være afgørende, at man ikke blot tilfredsstilles emotionelt, men at der også er et intellektuelt udfordrende element i dialogen (Habermas 1992, kap. 8), eftersom det er vejen frem i forhold til at kunne forholde sig rationelt til udfordringer, man måske ikke er opmærksom på i forvejen.

I forhold til den demokratiske opgave giver det derfor god mening at klæde journalister på til at kunne facilitere dialoger, hvor deltagerne udfordrer og flytter med hinanden. Så i stedet 
for at være mediator for information, kunne det være godt, hvis journalisten kunne blive moderator for dialog.

I den filosofiske litteratur er der et velartikuleret bud på, hvad der sker, når dialoger ikke er frugtbare og altså har brug for moderation. Den filosofisk hermeneutiske tradition har, særligt siden H.-G. Gadamer, påvist, at afstanden mellem dialogparterne er afgørende. Hvis der er alt for stor afstand mellem parterne, kan det være vanskeligt at få en dialog til at flytte noget (Gadamer 1959; 1966). Når parterne er langt fra hinanden, er det derfor afgørende, at man arbejder på at etablere en horiontsammensmeltning: Når man i en dialog skal opnå forståelse for, hvad den anden siger, er man nødt til at forstå den baggrund, som den anden taler ud fra. Det kan man ikke gøre, hvis man stædigt holder fast $\mathrm{i}$, at ens eget udgangspunkt er det eneste mulige. Derfor forudsætter enhver dialogisk forståelse ${ }^{6}$, at begge parter bevæger sig i retning af hinanden. Disse pointer har C. Taylor trukket ud på et lidt større samfundsmæssigt plan, idet han påpeger, at samfundsmæssige konflikter kan analyseres på samme måde (Taylor 1971; 1990; 1992).

En vigtig journalistisk opgave kan derfor være at bringe parter, der umiddelbart er meget forskellige fra hinanden, tættere på hinanden ved at hjælpe parterne til at se et muligt fælles udgangspunkt for deres uenighed, hvorved de kan blive i stand til i det mindste at forstå rationaliteten bag de forskellige synspunkter. Herved vil vi kunne opnå et samfund, hvor borgerne ikke nødvendigvis er mere enige, men hvor de i det mindste kan forstå, hvordan "de andre" kan være nået frem til deres synspunkter.

At oversætte den hermeneutiske analyse af, hvordan dialogisk forståelse finder sted, til en teori om, hvordan et demokratisk samfund fungerer bedst, er imidlertid ikke ukontroversielt. Det hermeneutiske billede på den sociale relation er fra mange forskellige sider blevet kritiseret for at være naivt (bl.a. i Foucault 1967; Habermas 1970; Derrida 1984; Honneth 2000). Når vi ser på ovenstående beskrivelse af, hvornår dialoger kan være ufrugtbare, så har vi foreløbig kun beskrevet den ene situation - nemlig den, hvor afstanden mellem parterne er for stor. Men rigtig ofte er det primære problem ikke, at vi ikke forstår hinanden, men at vi forstår hinanden alt for godt. Vi forstår hinanden så godt, at vi slet ikke udfordrer hinanden, lærer noget af hinanden, og måske 
forstår vi endda hinanden så godt, at vi mister blikket for, at der er noget, vi ikke forstår - fordi vi netop altid bliver bekræftet i, at vores baggrundsforståelse er god nok.

I et deliberativt perspektiv er det imidlertid altid vigtigt at have blik for de interesser, der ikke varetages af den til enhver tid gældende offentlige dagsorden. Derfor kan dialogens moderator i visse situationer have en påtrængende opgave i at lirke dialogernes gældende horisonter op, således at vi kan vinde blik for de oversete forhold eller problemer. Jeg har i anden sammenhæng (Hansen 2011; Hansen 2013) argumenteret for, at journalistikken til denne opgave kan have gavn af at tilegne sig diskursanalytiske eller dekonstruktive metoder eller færdigheder. Diskursanalysen (som den f.eks. artikuleres i Fairclough 1992) er et godt redskab til at vinde et blik for, hvordan den normale italesættelse af bestemte forhold altid er begrænset (fordi sproget tvinger os til at fokusere på bestemte sider af forholdet - på bekostning af andre). Diskursanalysen forsøger altså at gøre os bevidste om det, der ligger uden for den normale italesættelse.

Dekonstruktionen går derimod snarere ind i kernen af den normale håndtering af et forhold, et problem eller en udfordring og påviser, at for mange af vores kulturelle aktiviteter gælder det, at de er bygget op omkring en grundlæggende udfordring, der på den ene side skal løses - men på den anden side ikke kan løses (se en uddybning af denne pointe i Hansen 2011, s. 104-111; se også Derrida 1994; 1996).

For både diskursanalysen og dekonstruktionen gælder det, at når de lykkes, så viser de os kontingensen i vores almindelige italesættelse af et forhold, og herved bliver det muligt at sikre, at dialogen ikke udarter sig til en uproblematisk, rygklappende dialog, hvor vi bare hele tiden bekræfter hinanden i den gældende (begrænsede og begrænsende) italesættelse.

\section{Behovet for moderation af tavsheden}

En vigtig pointe i den dekonstruktive tilgang til samtale og vores praksis i verden er, at betydning kun opstår gennem tavshed (Derrida 1967, kap. VI; 1969, kap. II; Hansen 2009b): Et tegn kan kun blive betydningsfuldt ved at være adskilt fra andre tegn; 
der skal med andre ord være et mellemrum mellem tegnet og det andet. En betydning opstår ved, at noget trækkes ud som det væsentlige - den øvrige del af verden skubbes derved tilbage i baggrunden og bliver den tavse med-virkelighed, som gør, at det væsentlige fremtræder som påtrængende signifikant for os.

Når det nu er sådan med nødvendighed, kunne man indvende, at det næppe kan være en journalistisk opgave at modvirke det - fordi vi netop ikke kan opnå en situation, hvor alt er italesat. I en deliberativt demokratisk sammenhæng kan vi imidlertid ikke blive stående ved den konstatering. Et demokratisk samfund er jo netop defineret ved, at det er folket (ideelt set hele folket), der hersker over hele folket. I den demokratiske forvaltning skal vi derfor kunne tage hensyn til hele folket. Det er demokratiets nødvendige og uløselige opgave, og det er grunden til, at enhver demokratisk indretning altid må være vedvarende til forhandling (Agamben 1998, Introduction).

Internettet har dannet grobund for, at mange flere kan være aktivt til stede i den samfundsmæssige diskussion. For de gamle massemedier var det sådan, at hvis man ønskede at aktivere læserne, lytterne, seerne, så var det noget, man skulle arbejde meget aktivt med. I takt med at journalistiske medier i anden halvdel af det 20. århundrede bekendte sig til en rolle som forvaltere af almenvellet, blev dette betragtet som en påtrængende opgave: Journalistikken skulle aktivt gå ud og opsøge meninger og synspunkter hos det store flertal af borgere, der ikke selv havde evnerne til at tilkæmpe sig en offentlig stemme.

Denne opgave er kvantitativt blevet mindre påtrængende. Med internettets fremkomst er vi sat i en situation, hvor alle teknisk set kan blive en del af den aktive offentlighed. Når journalister skal stikke fingeren i folkedybet for at finde ud af, hvad der rører sig, kan han/hun tracke på den aktivitet, der finder sted på de sociale medier såsom YouTube, Twitter, Instagram og Facebook. Denne måde at lave journalistik på er naturligvis kun lødig, fordi en rigtig stor procentdel af befolkningen rent faktisk befinder sig på disse medier. ${ }^{7}$

Problemet er imidlertid, at det ikke kun er teknologien, der sætter rammerne for, hvem der kan være en del af offentligheden. Derfor er der stadig en gruppe af borgere, der ikke har en offentlig internetprofil. Og i takt med at denne gruppe kvantita- 
tivt bliver mindre, bliver opgaven med alligevel at give dem en offentlig stemme mindre synlig, men spørgsmålet er, om den også dermed bliver mindre påtrængende. I et demokratisk perspektiv afhænger dette naturligvis af, om de ikke-offentlige borgere repræsenterer nogle interesser, som har brug for en politisk opmærksomhed (og dermed offentlighed). Det kan man ikke give et endeligt svar på, da der kan være mange forskellige grunde til ikke at have en offentlig profil. Dog vil jeg her til slut forsøge at give et bud på, hvordan potentielt svage grupper af borgere i samfundet kan mangle en stemme.

Det drejer sig om en gruppe af borgere, som man kan kalde de kommunikativt udfordrede. Det kan dels være de ordblinde, der ikke kan læse eller skrive. Det kan også være borgere, der ikke formår fleksibelt at håndtere de interfaces, som stilles til rådighed på internettet - på en måde, som modsvarer deres ekspressive behov.

Dertil kommer en gruppe af borgere, som ikke kan formulere sig på en måde, som respekteres uden for den nærmeste vennekreds. Når f.eks. drengene på gadehjørnet i Vollsmose skal formulere deres mening om den siddende statsminister, kan man nok nemt risikere, at det kunne blive noget i stil med "Dø din fucking luder[karl]!”. ${ }^{8}$ Skulle sådan et udsagn finde sin vej til de sociale medier (hvilket de jævnligt gør), så er chancerne for, at de bliver taget alvorligt, nok minimale - og velsagtens med rette. Den politiske proces ville næppe blive mere frugtbar, hvis statsministre jævnligt skulle udsættes for sådanne trusler. Men det ændrer ikke ved, at den pågældende borger måske rummer et (udbredt) ressentiment, som måske i en mere velartikuleret formulering burde have offentlig bevågenhed som andet og mere end en utilstedelig fornærmelse.

Umiddelbart kunne man mene, at så snart truslen mod statsministeren finder frem til de sociale medier, så drejer det sig ikke længere om en tavshedens moderation, men derimod om en dialogens moderation. Opgaven består så at sige i at bringe en forståelse mellem et indvandrermiljø og en højrefløj i stand. Langt hen ad vejen er dette da også en mulig fortolkning.

I mange tilfælde vil udfordringen imidlertid være overhovedet at bringe den mere etablerede offentlighed til at indse nødvendigheden af at skulle forstå det/de synspunkt(er), som måtte 
ligge bag. De fleste af os vil være tilbøjelige til bare at slå det hen som en person, der trænger til at blive opdraget ordentligt. Og det er muligvis endda også en rigtig antagelse. Men en sådan bedrevidende antagelse ville nok i mange tilfælde kunne have godt af en analytisk efterprøvning, for ellers risikerer vi, at reelle uartikulerede ressentimenter forbliver uden for den offentlige opmærksomhed og dermed uden for en rationel drøftelse, hvorved den kan indtage uforudsigelige former. ${ }^{9}$

Det giver derfor god mening at hævde, at der ligger en journalistisk opgave i at skærpe offentlighedens blik for de tavse stemmer - og denne opgave overskrider moderationen af den pågående dialog. Opgaven består i at løfte de tavse stemmer ind i en offentlig bevågenhed.

I en vis forstand er dette jo ikke en ny opgave. I de traditionelle medier bestod journalisternes medieekspertise jo også netop i, at man kunne hjælpe borgerenes, kundernes og brugerenes stemmer ind i den offentlige bevågenhed, hvorved de gik fra at være usynlige til synlige i offentligheden. Men med de traditionelle massemedier var denne opgave så åbenlys, fordi det vitterligt kun var de særligt udvalgte, der kunne komme til orde. I de nyere internetbårne medier er denne opgave mere skjult - og derfor sværere at løfte.

\section{Fysisk og økonomisk understøttelse af den journalistiske intervention}

Det giver altså mening at påpege (mindst) tre overordnede deliberative opgaver for den fremtidige journalistik: En (a) traditionelt informerende, en (b) moderation af dialoger og en (c) moderation af tavshed.

En ting er at udpege de vigtige opgaver. Det nytter imidlertid ikke så meget, hvis der ikke også skabes nogle praktiske rammer, der giver rum for at løfte opgaverne. Som nævnt tidligere er de traditionelle indtægtskilder imidlertid faldende. F.eks. er oplagstallene på de regionale og landsdækkende hverdagsaviser ca. halveret i perioden 1997-2013. ${ }^{10}$ Selvom dette i sig selv ikke giver et fuldstændigt billede af den økonomiske situation for journalistisk baserede medier, giver det nok et meget godt billede 
af den generelle udfordring: Noget må gøres, men midlerne til at gøre det for er begrænsede.

Af de tre overordnede opgaver skriver (b) dialog-moderationen sig nok klarest ind i noget, der kan generere et umiddelbart kommercielt afkast, eftersom et medie med en frugtbar dialog alt andet lige vil have nemmere ved at generere aktivitet, hvilket (som tidligere nævnt) er en vigtig kommerciel parameter ved internetmedier. ${ }^{11}$ De (a) traditionelle journalistiske grunddyder for formidling, efterforskning og kritik har jo også traditionelt fundet et marked, men med den store udvekslingskultur på internettet har det vist sig tiltagende svært for det enkelte medie selv at høste den fulde gevinst af det bagvedliggende arbejde. Endelig er det ikke umiddelbart indlysende, at (c) tavshedens moderation skulle være en kommercielt attraktiv opgave.

Spørgsmålet er derfor, om man umiddelbart kan forvente, at et kommercielt presset medielandskab er tilstrækkelig risikovilligt til at opdyrke nye journalistiske grunddyder. Det er ikke ærindet for denne artikel at gøre sig klog på, hvordan man bedst driver en forretning i et presset marked. Men eftersom udgangspunktet for hele analysen er det deliberative demokrati, kunne det være en overvejelse værd at rette de offentlige støtteformer mere direkte mod en understøttelse af ovenstående opgaver (særligt mediestøtten og public service-lovgivningen). Den nye model for fordeling af mediestøtte (januar 2014) taler om at understøtte den demokratiske debat, og der oprettes også en innovationspulje til at støtte nye eksperimenter. Det er et lille fremskridt i forhold til den gamle aftale, men det kunne nok være tjenligt, hvis man kunne være lidt mere eksplicit om, hvad man mener, når man taler om den gode demokratiske debat.

Opgaven for de offentligt støttede public service-medier er stort set kontinuerligt til forhandling - særligt i forbindelse med skift i politisk farve for siddende regeringer (se f.eks. Mouritsen 2006). Meget ofte foregår denne debat som en diskussion af, hvorvidt disse medier skævvrider markedet og dermed underminerer de kommercielle mediers markedsgrundlag.

Måske ville relevansen af offentligt understøttede public service-medier blive mere tydelig, hvis det blev klart, hvad det mere præcist er, vi alle kan vinde gennem disse medier. Public service-medierne kunne oplagt bruges til at eksperimentere med 
medieformer, der giver rum for det, som er vigtigt i et deliberativt demokrati.

Vel at mærke med et blik på også de nye udfordringer for medierne. I forlængelse af de udfordringer, som er blevet udfoldet i denne artikel, kunne man overveje at gøre det klart, at de offentligt understøttede public service-medier havde en særlig opgave i at finde nogle former for journalistisk intervention, som kunne løfte opgaven med at moderere samfundets dialog og tavshed. ${ }^{12}$

På den måde ville de offentligt støttede public servicemedier ikke nødvendigvis skulle betragtes som konkurrenter til de rent kommercielle medier - de kunne tværtimod komme til at fungere som isbrydere, der skaber et nyt frirum i et mediemæssigt farvand, der både kommercielt og demokratisk for nærværende fryser mere og mere til.

\section{REFERENCER}

Adorno, Theodor W (1966): Negative Dialektik, Frankfurt am Main: Suhrkamp.

Agamben, Giorgio (1998): Homo sacer: sovereign power and bare life, Stanford, Calif.: Stanford University Press.

Anderson, Benedict (1991): Imagined communities: reflections on the origin and spread of nationalism, 2. ed., London: Verso.

Andrejevic, Mark (2007): "Surveillance in the Digital Enclosure", The Communication Review, vol. 10, nr. 4, s. 295-317.

Bjerg, Lars (2009): Den gode journalist: etik, voerdier og kvalitet $i$ journalistik, Århus: Ajour.

Bro, Peter (2009): Menneskelig kommunikation, fra telegrafisternes til journalisternes tidsalder, Odense: Syddansk Universitetsforlag.

Debrouwere, Stijn (2012): "Fungible", http://stdout.be/2012/05/04/fungible/.

Derrida, Jacques (1996): Apories:mourir, s'attendre aux "limites de la vérité”, Paris: Galilée.

Derrida, Jacques (1984): "Bonnes volontés de puissance. Une réponse à Hans-Georg Gadamer”, Revue intenationale de philosophie, vol. 151, s. 333-347.

Derrida, Jacques (1994): Force de loi:le "Fondement mystique de l'autorité", Paris: Galilée. 
Derrida, Jacques (1969): “La double seance”, i Derrida, Jacques (red.), La dissémination, 1972. ed., Paris: Éditions du Seuil.

Derrida, Jacques (1967): La voix et le phénomène: introduction au problème du signe dans la phénomenologie de Husserl, Paris: Presses Universitaires de France.

Dewey, John (1920): Reconstruction in philosophy, Boston: Beacon Press. Fairclough, Norman (1992): Discourse and social change, Cambridge, UK; Cambridge, MA: Polity Press.

Foucault, Michel (1969): L'archéologie du savoir, Paris: Gallimard.

Foucault, Michel (1967): “Nietzsche, Freud, Marx”, i Defert, Daniel; Ewald, François; Lagrange, Jacques (red.), 1994. ed., Paris: Galimard, (Dits et écrits 1954-1988), s. 592-607.

Gadamer, Hans-Georg (1966): “Die Unfähigkeit zum Gespräch”, i Wahrheit und Methode: Ergänzungen; Register, 2. Aufl. (durchgesehen), Tübingen: J. C. B. Mohr (P. Siebeck).

Gadamer, Hans-Georg (1959): “Vom Zirkel des Verstehens”, i Wahrheit und Methode: Ergänzungen ; Register, 2. Aufl. (durchgesehen), Tübingen: J. C. B. Mohr (P. Siebeck).

Habermas, Jürgen (1970): “Der Universalitätsanspruch der Hermeutik”, i Zur Logik der Sozialwissenschaften. Erweiterte Ausgabe (1982), Frankfurt am Main: Suhrkamp Verlag, s. 331-366.

Habermas, Jürgen (1992): Faktizität und Geltung: Beiträge zur Diskurstheorie des Rechts und des demokratischen Rechtsstaats, Frankfurt am Main: Suhrkamp.

Habermas, Jürgen (1962): Strukturwandel der Öffentlichkeit: Untersuchungen zu einer Kategorie der bürgerlichen Gesellschaft, 2. ed., Frankfurt am Main: Suhrkamp.

Hansen, Ejvind (2009a): "Actuvirtualized Activity and Passivity in the Political Sphere”, i Boyd, Scott H.; Gil, Ana Cristina; Wong, Baldwin (red.), Culture, Politics, Ethics: Interdisciplinary Perspectives, Salzburg: Inter-disciplinary.net, s. 183-190.

Hansen, Ejvind (2013): “Aporias of Digital Journalism”, Journalism - Theory, practice and criticism, vol. 14, nr. 5, s. 678-694.

Hansen, Ejvind (2009b): "Communicative In-Betweens of Email Communication”, Techné: Research in Philosophy and Technology, (Techné: Research in Philosophy and Technology), vol. 13, nr. 1, s. 13-26.

Hansen, Ejvind (2011): "Den dialog-udfordrende journalist”, i Buch, Roger (red.), Forandringens journalistik. 40 års tilbageblik, Aarhus: Forlaget Ajour, s. 97-117. 
Hansen, Ejvind (2010): "Kantian antinomies in digital communications media”, Telos, vol. 150, s. 137-142.

Heidegger, Martin (1927): Sein und Zeit, Tübingen: Niemeyer.

Honneth, Axel (1992): Kampf um Anerkennung : zur moralischen Grammatik sozialer Konflikte, Frankfurt am Main: Suhrkamp.

Honneth, Axel (2000): "Von der zerstörerischen Kraft des Dritten”, i Unsichtbarkeit. Stationen einer Theorie der Intersubjektivität, Frankfurt am Main: Suhrkamp, s. 49-70.

Husserl, Edmund (1935): Die Krisis der Europäischen Wissenschaften und die Transzendentale Phänomenologie Ein Einleitung in die Phänomenologische Philosophie, Biemel, Walter (red.), Haag: Martinus Nijhoff, (Husserliana 6).

Jønch-Clausen, Heidi; Lyngbye, Lise (2007): “Hvad er fairness?”, Journalistica - Tidsskrift for forskning i journalistik, nr. 5, s. 91-108.

Lyotard, Jean-François (1979): La condition postmoderne: rapport sur le savoir, Paris: Éditions de Minuit, (Collection Critique).

Mouritsen, Per (2006): "I folkets tjeneste: Public service som omstridt begreb", Journalistica - Tidsskrift for forskning i journalistik, (Selvopfattelse, public service, kvalitet), nr. 3, s. 65-85.

Pariser, Eli (2011): The Filter Bubble. What the Internet is Hiding From You, New York: Penguin Press.

Rorty, Richard (1989): Contingency, irony, and solidarity, Cambridge; New York: Cambridge University Press.

Rorty, Richard (1979): Philosophy and the mirror of nature, Princeton: Princeton University Press.

Taylor, Charles (1990): “Comparison, History, Truth”, i Philosophical arguments, Cambridge, Mass: Harvard University Press, s. 146-164.

Taylor, Charles (1971): "Interpretation and the sciences of man", i Philosophy and the human sciences., Cambridge; New York: Cambridge University Press, (Philosophical papers), s. 15-57.

Taylor, Charles (1992): “The Politics of Recognition”, i Philosophical arguments, Cambridge, Mass: Harvard University Press, s. 225-256.

\section{NOTER}

1 Massemedierne er i en vis forstand kun det ene teknologiske ben i dette. Uden en understøttelse af (bl.a.) telegrafen, telefax, telefon og satellit ville informationsgangen til medierne være besværliggjort så meget, at store dele af det samfund, som medierne rækker ud til, ikke 
kunne være blevet repræsenteret på en rimelig måde (se Bro 2009 for en uddybning af denne pointe).

2 Det er i denne sammenhæng vigtigt at påpege, at betydningen af "kritisk" har varieret meget op gennem historien. Siden anden halvdel af det 20. århundrede har den journalistiske profession været holdt op imod idealer om at repræsentere en form for almen stemme, der skulle repræsentere "folket" og trænge bagom magthavernes forsøg på at skjule objektivt kritisable forhold. Tidligere i historien foregik den "kritiske" sortering imidlertid primært på baggrund af specifikke samfundsinteressers perspektiv, uden en sådan implikation hermed repræsenterede almenvellet.

3 Jønch-Clausen og Lyngbye har vist, at begrebet "fairness" ganske vist spiller en stor rolle i den journalistiske selvforståelse, men at der ikke findes en faktisk konsensus om, hvad det egentlig betyder (JønchClausen og Lyngbye 2007).

4 Man burde naturligvis tage forbehold for problemer omkring digitaliseringsprocessen. Man kan (f.eks.) meningsfuldt diskutere, om den digitale gengivelse af tonerne fra en violin giver et rimeligt billede af (information om) den oprindelige (analoge) lyd. I forhold til den journalistiske opgave er dette dog ikke en grundlæggende problematik. Et bud på en mere filosofisk behandling af dette problem kan findes i Hansen 2010.

5 Her antager jeg altså, at dette deliberative ideal har en relevans for vores demokrati og samfund. Som det vil blive klart i det følgende, ligger der i denne implikation imidlertid ikke så meget andet end en forudsætning om, at vi får et bedre demokrati, hvis vi handler på baggrund af en oplyst forståelse, hvor der lyttes til alle, og hvor fornuftig refleksion i en eller anden forstand også skal spille en rolle, når vi overvejer, hvordan vi skal håndtere samfundets udfordringer. Jeg finder således dette fint i tråd med en almindelig antagelse i de fleste vestlige samfund.

6 Bemærk, at "forståelse" ikke nødvendigvis betyder "enighed". For Gadamer er hovedærindet for en dialogisk udveksling ikke nødvendigvis, at man bliver enige, men at man forstår hinandens udgangspunkt.

7 Dertil kommer, at det også forudsætter en væsentlig grad af kildekritik, idet man skal kunne sortere i kunstige profiler og strategisk bevidst igangsatte kampagner fra stærke interessenter i samfundet.

8 http://www.b.dk/nationalt/18-aarig-doemt-for-trusler-mod-thor- 
ning

9 EkstraBladet har i skrivende stund netop meddelt, at de vil begynde at formulere en modstemme til det hidtil stort set ikke-modererede community NATIONEN!. Det er endnu for tidligt at konkludere for håndfast på dette, men tiltaget kunne bestemt godt være et skridt i den rigtige retning, idet stemmerne så netop bliver taget mere alvorligt af den mere anerkendte offentlighed. Ikke nødvendigvis som en blind accept, men som noget, der skal høres og imødegås i en dialog.

${ }^{10}$ Kilde: http://tns-gallup.dk/statistik/laesertal

${ }^{11}$ Udfordringen består så bare i at høste den økonomiske gevinst uden at stække aktiviteten, hvilket givetvis er en af de største udfordringer ved at indføre betalingsmure for brugen af offentlige medier.

${ }^{12}$ En opgave, hvor de eksisterende offentligt støttede public servicemedier bestemt har et stort udviklingspotentiale. 